\title{
ANTI-CANCER EFFECTS OF POLYSACCHARIDE AND PHYCOCYANIN FROM PORPHYRA YEZOENSIS
}

Lu-Xi Zhang

Key Laboratory of Aquatic Genetic Resources and Aquacultural Ecosystem, The Ministry of Agriculture, Shanghai Ocean University, Shanghai, P.R. China.

Chun-Er Cai

Key Laboratory of Aquatic Genetic Resources and Aquacultural Ecosystem, The Ministry of Agriculture, Shanghai Ocean University, Shanghai, P.R. China.

Ting-Ting Guo

Key Laboratory of Aquatic Genetic Resources and Aquacultural Ecosystem, The Ministry of Agriculture, Shanghai Ocean University, Shanghai, P.R. China.

Jia-Wen Gu

Key Laboratory of Aquatic Genetic Resources and Aquacultural Ecosystem, The Ministry of Agriculture, Shanghai Ocean University, Shanghai, P.R. China.

Hong-Li Xu

Key Laboratory of Aquatic Genetic Resources and Aquacultural Ecosystem, The Ministry of Agriculture, Shanghai Ocean University, Shanghai, P.R. China.

See next page for additional authors

Follow this and additional works at: https://jmstt.ntou.edu.tw/journal

Part of the Life Sciences Commons

\section{Recommended Citation}

Zhang, Lu-Xi; Cai, Chun-Er; Guo, Ting-Ting; Gu, Jia-Wen; Xu, Hong-Li; Zhou, Yun; Wang, Yuan; Liu, Cheng-Chu; and He, Pei-Min (2011) "ANTI-CANCER EFFECTS OF POLYSACCHARIDE AND PHYCOCYANIN FROM PORPHYRA YEZOENSIS," Journal of Marine Science and Technology. Vol. 19: Iss. 4, Article 6.

DOI: $10.51400 / 2709-6998.2178$

Available at: https://jmstt.ntou.edu.tw/journal/vol19/iss4/6

This Research Article is brought to you for free and open access by Journal of Marine Science and Technology. It has been accepted for inclusion in Journal of Marine Science and Technology by an authorized editor of Journal of Marine Science and Technology. 


\section{ANTI-CANCER EFFECTS OF POLYSACCHARIDE AND PHYCOCYANIN FROM PORPHYRA YEZOENSIS}

\section{Acknowledgements}

We are grateful to professor Wei-hua Feng (Department of Molecular and Biochemical, Second Military Medical University) for helpful advice to our studies. This research was financially supported by State 863 Programs (No. 2006AA10 Z323 and No. 2007AA09Z406), Key Laboratory of Exploration and Utilization of Aquatic Genetic Resources, Shanghai Ocean University, Ministry of Education (No. KFT 2008-12), Program of Shanghai Subject Chief Scientist (08XD14037), Project of Shanghai Science and Technology Commission (08540702600), Shanghai Education Committee of China (Preponderant Subject Program\# S30701) and Shanghai Science Committee (Bio-Medicine Key Project \#054319936, Pujiang Plan \#05PJ14086).

\section{Authors}

Lu-Xi Zhang, Chun-Er Cai, Ting-Ting Guo, Jia-Wen Gu, Hong-Li Xu, Yun Zhou, Yuan Wang, Cheng-Chu Liu, and Pei-Min He 


\title{
ANTI-CANCER EFFECTS OF POLYSACCHARIDE AND PHYCOCYANIN FROM PORPHYRA YEZOENSIS
}

\author{
Lu-Xi Zhang*, Chun-Er Cai*, Ting-Ting Guo*, Jia-Wen Gu*, Hong-Li Xu*, \\ Yun Zhou*, Yuan Wang*, Cheng-Chu Liu*, and Pei-Min He*
}

Key words: anti-cancer effects, polysaccharide, phycocyanin, Porphyra yezoensis.

\begin{abstract}
In this paper, phycocyanin and one component (PY-D2) in polysaccharide were obtained from Porphyra yezoensis to study for their potential anti-tumor effects. MTT proliferation assays showed that, at concentration of $500 \mathrm{mg} / \mathrm{L}$ for $72 \mathrm{~h}$, PY-D2 treatment significantly inhibited the growth of four tumor cell lines, HO-8910, MCF-7, K562 and SMMC-7721, with the respective inhibition rates of $21.2 \%, 23.6 \%, 19.8 \%$, and $21 \%$. Flow cytometry analysis indicated that the anti-tumor effect of PY-D2 was associated with the cell cycle arrest at G0/G1 or G2/M check-points. Two cancer cell lines, Hep-2 and A375 were treated by different concentrations of phycocyanin, followed by radiation with $\mathrm{He}-\mathrm{Ne}$ laser at the density of $20 \mathrm{~J} / \mathrm{cm}^{2}$ and the wavelength of $632 \mathrm{~nm}$. MTT assays displayed the minimal survival rate of $29.8 \%$ (Hep-2) and $16.2 \%$ (A375) at $100 \mu \mathrm{g} / \mathrm{ml}$ and $165 \mu \mathrm{g} / \mathrm{ml}$ respectively. These results suggest that both polysaccharide and phycocyanin from Porphyra yezoensis might be useful in the treatment of human cancers. These results suggest that phycocyanin and one component (PY-D2) in polysaccharide which had been obtained both from Porphyra yezoensis were potential medicaments in the treatment of some kinds of human cancers.
\end{abstract}

\section{INTRODUCTION}

Polysaccharide and phycobiliprotein were two important bioactive substances of Porphyra yezoensis, an algal species well known for its nutritional value and widely used as a healthy food in Asia [13, 18]. Polysaccharide has attracted great attentions for its benefits to human health, such as reducing blood pressure [31], anti-fatigue effect, improving the

Paper submitted 06/09/09; revised 11/24/09; accepted 03/31/10. Author for correspondence: Pei-Min He (e-mail:pmhe@shou.edu.cn).

*Key Laboratory of Aquatic Genetic Resources and Aquacultural Ecosystem, The Ministry of Agriculture, Shanghai Ocean University, Shanghai, P.R. China. function of immune system [10, 38] and protecting against hepatotoxicity induced by carbon tetrachloride [9]. On the other hand, phycocyanin, a phycobiliprotein of the alga, has also been widely used as a food additive and cosmetic colorant [5]. Phycocyanin extracted from Spirulina platensis displayed favorable health benefits such as improving immune function, promoting zooblast regeneration and inhibiting the growth of cancer cells [30]. Since phycocyanin is photosensitive, it has been proposed as a new photosensitizer for photodynamic therapy $[3,22,23,27]$.

Previous studies have already suggested that both polysaccharides and phycobiliproteins from certain algal species may inhibit the growth of tumor cells [3, 16, 22-24, 27]. To further confirm such findings and to explore the health benefits of Porphyra yezoensis, we studied effects of polysaccharide and phycocyanin on the growth of human tumor cell lines.

\section{MATERIALS AND METHODS}

\section{Polysaccharide and Phycocyanin}

Polysaccharide was purified and two single components PY-D1 and PY-D2 were obtained following the previous protocol $[8,9]$. Flesh blades of Porphyra yezoensis were dried and cut into small pieces. Lipids were removed by alcohol circumfluence and polysaccharides were extracted with hot water for $3 \mathrm{~h}$. The extract added with mixture of chloroform and butanol were vibrated at $350 \mathrm{rpm}$ for a while, followed by $15 \mathrm{~min}$ centrifugalism at $4000 \mathrm{rpm}$ [20]. The precipitation removed and the polysaccharides in suspension were precipitated by $95 \%$ alcohol before being further purified by DEAE-52 column and Sephadex G-200 column. In DEAE-52 chromatography, PY-D1 and PY-D2 were eluted with distilled water and $3 \mathrm{~N} \mathrm{NaCl}$ at $0.5 \mathrm{ml} / \mathrm{min}$ [21].

The procedures of isolation and purification of phycocyanin were described previously [2]. Briefly, total proteins were extracted from thallus of Porphyra yezoensis through the combination of dissolving-bulging and tissue-homogenator methods. After the precipitation by $20 \%$ ammonium sulphate, phycocyanin in the upper solution was further precipitated by 
$50 \%$ ammonium sulphate. After another two rounds of similar precipitation with $10 \%$ and $40 \%$ ammonium sulphate, the phycocyanin precipitation was resuspended into $50 \mathrm{mM}$ phosphate buffer ( $\mathrm{pH}$ 6.8), and further desalted and purified by hydroxylapatite column. The purity of final phycocyanin preparation was determined by spectrophotometry.

\section{Culture Media and Chemicals}

The cell culture media RPMI 1640, DMEM, and fetal bovine serum (FBS) were purchased from Gibco. MTT and SDS was purchased from Sigma. DEAE-52 and Sephadex G-200 were purchased from GE. Other chemicals (ammonium sulphate, alcohol, sodium chloride, chloroform, calcium chloride anhydrous, disodium hydrogen phosphate dodecahydrate, sodium dihydrogen phosphate dehydrate) were of analytical grade from commercial sources.

\section{Tumor Cell Lines}

Human ovarian cancer cell line HO-8910, human breast cancer cell line MCF-7, human leukemia cell line K562 and human hepatocellular carcinoma cell line SMMC-7721 were kindly provided by Second Military Medical University. Human laryngeal carcinoma cell line Hep-2 and human malignant melanoma cell line A375 were purchased from Chinese Academy of Sciences.

\section{MTT Proliferation Assays for Cells after PY-D2 Treatment}

HO-8910, MCF-7, K562, and SMMC-7721 cells were cultured in RPMI1640 media containing 10\% FBS. $100 \mu \mathrm{l}$ of cells was plated into each well of a 96-well plate at the density of $5 \times 10^{5} / \mathrm{ml}$. Then the cells were incubated at $37^{\circ} \mathrm{C}$ with $5 \% \mathrm{CO}_{2} .10 \mu \mathrm{l}$ of PY-D2 dissolved in $0.9 \%$ of $\mathrm{NaCl}$ solution was added into each well $24 \mathrm{~h}$ later, to the final concentrations of $5 \mathrm{mg} / \mathrm{L}, 25 \mathrm{mg} / \mathrm{L}, 50 \mathrm{mg} / \mathrm{L}, 100 \mathrm{mg} / \mathrm{L}, 500 \mathrm{mg} / \mathrm{L}$ and 1000 $\mathrm{mg} / \mathrm{L}$ to HO-8910 and MCF-7 cells, as well as $25 \mathrm{mg} / \mathrm{L}, 50$ $\mathrm{mg} / \mathrm{L}, 100 \mathrm{mg} / \mathrm{L}, 500 \mathrm{mg} / \mathrm{L}$ to $\mathrm{K} 562$ and SMMC-7721 cells. $0.9 \%$ of $\mathrm{NaCl}$ solution alone was used as the control for the experiment. Each concentration group for each cell line had 12 replicates. After $72 \mathrm{~h}, 10 \mu \mathrm{l}$ of $5 \mathrm{~g} / \mathrm{L}$ MTT was added into each well and cells were incubated for another $4-6 \mathrm{~h}$ at $37^{\circ} \mathrm{C}$. Then $10 \%$ SDS was added and the OD values at $595 \mathrm{~nm}$ was measured with a microplate reader $(\lambda=595 \mathrm{~nm})$ in the following day. The cell growth inhibition rate was calculated according to the following formula: Inhibition rate $=\left(\left(\overline{\mathrm{A}}_{\text {control }}-\right.\right.$ $\left.\left.\overline{\mathrm{A}}_{\mathrm{PY}-\mathrm{D} 2}\right) / \overline{\mathrm{A}}_{\text {control }}\right) \times 100 \%$.

\section{Flow Cytometry Analysis}

Flow cytometry analysis was performed similarly as described previously [40]. Two groups of cells were analyzed the $0.9 \% \mathrm{NaCl}$ solution control group and the $500 \mathrm{mg} / \mathrm{L}$ PY-D2 treatment group. The cultured cells in the logarithmic phase were centrifuged, the cell pellets were resuspended in $70 \%$ ethanol, and fixed at $-20^{\circ} \mathrm{C}$ overnight. Then the cells were washed twice with PBS, and incubated with $1 \mathrm{mg} / \mathrm{ml}$ RNaseA and $50 \mu \mathrm{g} / \mathrm{ml}$ proteinase inhibitor at room temperature in dark for $30 \mathrm{~min}$. Treated cells were then stained for their nuclear contents by Propidium Iodide (PI), and analyzed by flow cytometry for the cell cycle progression.

\section{MTT Proliferation Assays for Cells after Phycocyanin Treatment}

Hep-2 and A375 cells were first cultured in RPMI1640 media containing $10 \%$ FBS. Then the cultured cells in the logarithmic phase were centrifuged, the cell pellets were resuspended in RPMI1640. $50 \mu \mathrm{l}$ of the above cells were plated into each well of a 96-well plate at the density of $10^{6} / \mathrm{ml}$. Then the cells were incubated at $37^{\circ} \mathrm{C}$ with $5 \% \mathrm{CO}_{2}$. The concentrations of phycocyanin in the four groups of Hep-2 cells were set to $5 \mu \mathrm{g} / \mathrm{ml}, 25 \mu \mathrm{g} / \mathrm{ml}, 50 \mu \mathrm{g} / \mathrm{ml}$ and $100 \mu \mathrm{g} / \mathrm{ml}$, respectively; and those in the five A375 groups were $10 \mu \mathrm{g} / \mathrm{ml}, 25 \mu \mathrm{g} / \mathrm{ml}, 50$ $\mu \mathrm{g} / \mathrm{ml}, 100 \mu \mathrm{g} / \mathrm{ml}$ and $165 \mu \mathrm{g} / \mathrm{ml}$, respectively. Each concentration group for each cell line included 6 replicates. After $4 \mathrm{~h}$ of incubation with phycocyanin, the treated cells were irradiated with $\mathrm{He}-\mathrm{Ne}$ laser at a density of $20 \mathrm{~J} / \mathrm{cm}^{2}$ and a wavelength of $632 \mathrm{~nm}$. Then $50 \mu \mathrm{l}$ of RPMI 1640 containing 20\% FBS was added into each well. After $72 \mathrm{~h}, 10 \mu \mathrm{l}$ of $5 \mathrm{~g} / \mathrm{L}$ MTT was added into each well and incubated for another 4-6 $\mathrm{h}$ at $37^{\circ} \mathrm{C}$. Then $10 \%$ SDS was added and the OD values were obtained by microplate reader $(\lambda=595 \mathrm{~nm})$ in the following day. The none-treatment group was set as the normal control and the laser irradiated group without phycocyanin treatment was set as the negative control. The cell survival rate of cells after radiation was calculated according to the formula: Survival rate $=\left(\overline{\mathrm{A}}_{\text {phycocyanin/laser }} / \overline{\mathrm{A}}_{\text {normal control }}\right) \times 100 \%$. In case for the calculation of survival rate of negative control, $\overline{\mathrm{A}}_{\text {phycocyanin/laser }}$ was replaced with $\overline{\mathrm{A}}_{\text {laser }}$.

\section{Statistical Analysis}

All the data were expressed as mean $\pm \mathrm{SD}$ and subjected to a one-way analysis of variance (ANOVA) followed by a $t$-test for multiple comparisons. For a single comparison, the significance of differences between the means was determined by the Student's $t$-test. $p<0.05$ was considered as statistically significant.

\section{RESULTS}

\section{Purification of Polysaccharide and Phycocyanin Extracted from Porphyra yezoensis}

Fig. 1 was the chromatogram of the polysaccharide elution from DEAE-52 column. The two distinct and sharp absorption peaks indicated a good separation of two components by the column. The purified polysaccharide, named PY-D1 and PY-D2, were mainly non-anion and anion polysaccharides, which became white flocculus after lyophilization.

C-phycocyanin crude extracted from Porphyra yezoensis 


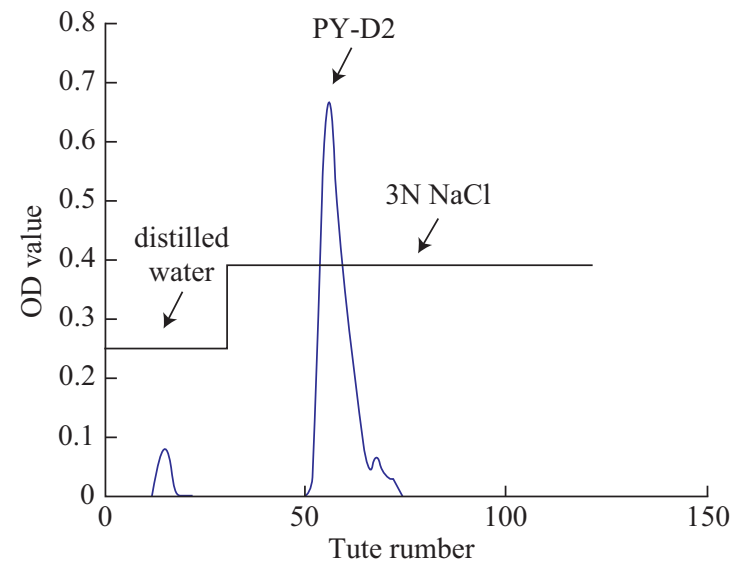

Fig. 1. Chromatogram of polysaccharide extracted from Porphyra yezoensis. PY-D1 was unabsorbed and eluted by distilled water, while PY-D2 was absorbed by DEAE-52 column and eluted by 3 $\mathrm{N} \mathrm{NaCl}$ at $0.5 \mathrm{ml} / \mathrm{min}$.

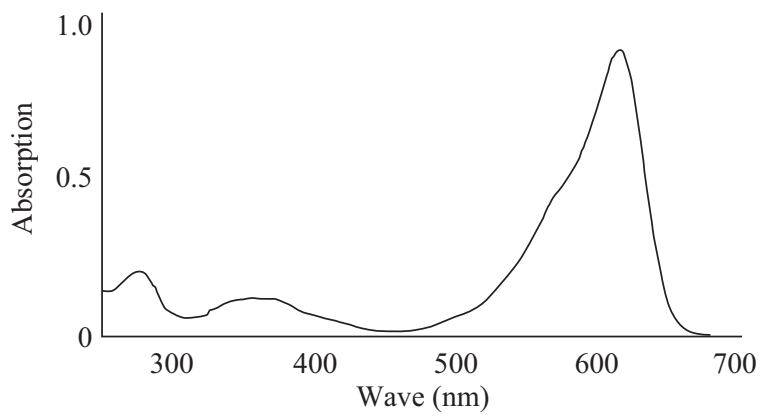

Fig. 2. Absorption of C-phycocyanin from Porphyra yezoensis after hydroxylapatite chromatography.

was purified by hydroxylapatite chromatography. The chromatogram in Fig. 2 shows that the absorption peak at $615 \mathrm{~nm}$ for phycocyanin exceeded 4.5 fold of the absorption peak at $280 \mathrm{~nm}$, indicating a good purity of phycocyanin. The yield of phycocyanin was determined to be $0.07 \%$ of dry weight by spectrophotometry.

\section{Inhibitory Effect of Polysaccharide on the Growth of Four Cancer Cell Lines}

The effects of polysaccharide PY-D2 on the growth of HO-8910, MCF-7, K562 and SMMC-7721 cells were investigated. Fig. 3 shows that PY-D2 significantly inhibited the growth of all tumor cell lines dose-dependently. The inhibiting effect of PY-D2 on MCF-7 was stronger than on the other three tumor cell lines under the same concentrations. MCF-7 cell growth was inhibited by $23.6 \%$ and $32.5 \%(p<0.001)$, respectively, under concentrations of 500 and $1000 \mathrm{mg} / \mathrm{L}$ PY-D2 (Fig. 3(a)); HO-8910 cell growth rate was inhibited $23.9 \%(p<0.001)$ by PY-D2 at concentration of $1000 \mathrm{mg} / \mathrm{L}$ (Fig. 3(b)); the growth rates of K562 and SMMC-7721 cells were inhibited by $19.8 \%$ (Fig. 3(c)) and 21\% ( $p<0.001)$, respectively (Fig. 3(d)), under $500 \mathrm{mg} / \mathrm{L}$ PY-D2.

\section{Flow Cytometry Analysis of Tumor Cell Lines Treated with Polysaccharide}

Flow cytometry analysis showed rangement in the percentages of cells under different cell cycle stages after PY-D2 treatment. For SMMC-7721 cell line, the percentage of G0/G1 stage cells increased while that of $\mathrm{G} 2 / \mathrm{M}$ stage cells decreased; there was no significant change in the percentage of S stage cells (Fig. 4(a)). For the HO-8910 cell line, the percentage of G0/G1 stage cells increased while that of S stage cells decreased; no significant change in the percentage of G2/M stage cells was observed (Fig. 4(b)). For the MCF-7 cell line and K562 cell line, the percentage of G0/G1 stage cells decreased while that of the $\mathrm{G} 2 / \mathrm{M}$ stage cells increased; no significant change in the percentage of $\mathrm{S}$ stage cells was observed (Fig. 4(c), 4(d)).

\section{Inhibitory Effect of Phycocyanin on the Growth of Cancer Cells}

Phycocyanin treatment at concentrations higher than 5 $\mu \mathrm{g} / \mathrm{ml}$ caused dose-dependent inhibition of the growth of Hep-2 cells ( $p<0.01$, Fig. 5). The survival rates of Hep-2 cells reduced to $83.1 \%, 53.8 \%$ and $29.8 \%$, respectively, correspond to the baseline survival rate of the non-treatment group (all $p$ values $<0.01$ ), under the three increasing concentrations of phycocyanin. The laser treatment alone also showed some inhibitory effect on the growth of Hep- 2 cells, with the cell survival rate reduced to $89.2 \%(p<0.05)$.

In the experiments with A375 cells, all five dosage levels of phycocyanin significantly inhibited the growth of A375 cells (all $p$ values $<0.01$ ). With the increase of phycocyanin concentration, the survival rates of A375 were reduced to $81.3 \%$, $68.0 \%, 17.2 \%, 16.2 \%$ and $11.8 \%$ respectively (all $p$ values $<$ 0.01), showing a dose-dependent effect (Fig. 6). In the experiments with A375 cells, the cell survival rate of the laser treatment group without PY-D2 treatment was $86.4 \%$ ( $p<$ $0.05)$, which was similar to the laser group of Hep-2 cells.

\section{DISCUSSION}

Polysaccharides from Porphyra yezoensis have been reported to accelerate the proliferation of mouse spleen lymphocytes, marrow cells and macrophages [10, 34, 38]. Our data showed that they also inhibited the growth of a panel of human tumor cell lines, and such effects were dose-dependent.

Cell cycle is very important to the regulation of tumor growth. There are two checkpoints of the cell cycle: the G1 and the G2 checkpoints. The G1 checkpoint decides whether the cells enter S stage via G1 stage, and it is the driving force of the cell cycle. The G2 checkpoint is the monitoring mechanism of the cell cycle [35]; it ensures the high accuracy of DNA duplication and prevents cells with damaged or unduplicated DNAs from entering mitosis (M) stage [11, 26]. More and more scholars are attaching importance to the studies of inhibiting human tumor growth through the regulation of cell cycle of tumor cells [6]. In this study, the flow 


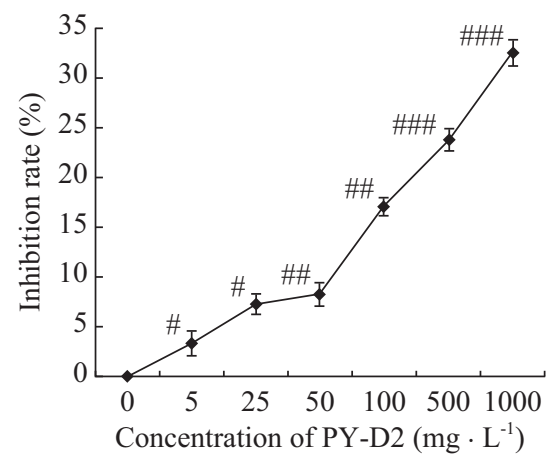

(a)

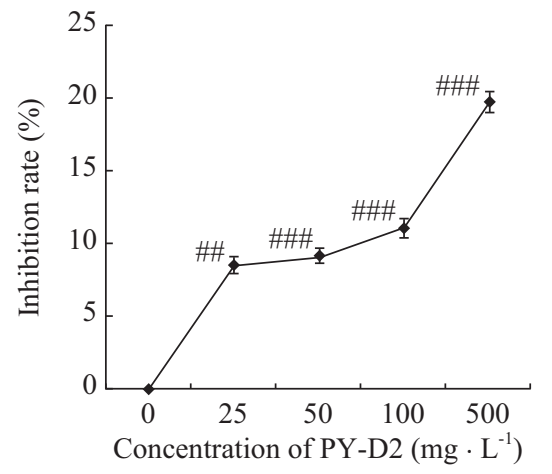

(c)

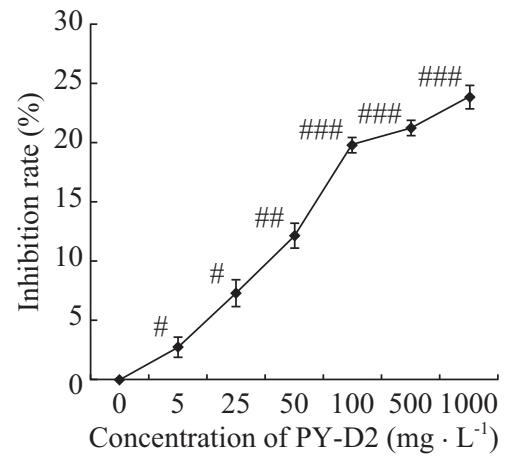

(b)

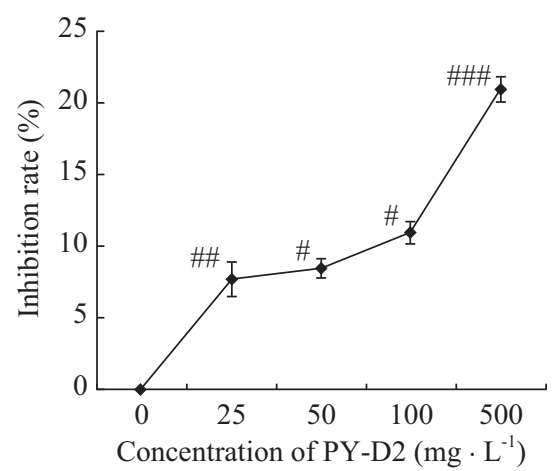

(d)

Fig. 3. (a) Inhibiting effect of PY-D2 on proliferation of MCF-7 cells after $72 \mathrm{~h}$ treatment. ${ }^{\#} p<0.05,{ }^{\#} p<0.01,{ }^{\# \#} p<0.001$ as compared with control (0), $\mathbf{n}=12, \overline{\mathrm{X}} \pm \mathrm{S}$, (b) Inhibiting effect of PY-D2 on proliferation of HO-8910 cells after $72 \mathrm{~h}$ treatment. ${ }^{\#} p<0.05,{ }^{\#} p<0.01,{ }^{\# \#} p<0.001$ as compared with control (0), $n=12, \bar{X} \pm S$, (c) Inhibiting effect of PY-D2 on proliferation of K562 cells after 72 h treatment. ${ }^{\# p}<0.05,{ }^{\# \#} p<0.01$, \#\# $p<0.001$ as compared with control $(0), n=12, \bar{X} \pm S$, (d) Inhibiting effect of PY-D2 on proliferation of SMMC-7721 cells after $72 \mathrm{~h}$ treatment. ${ }_{p}^{\#}<0.05,{ }^{\#} p<0.01,{ }^{\#} p<0.001$ as compared with control $(0), \mathrm{n}=12, \overline{\mathrm{X}} \pm \mathrm{S}$.

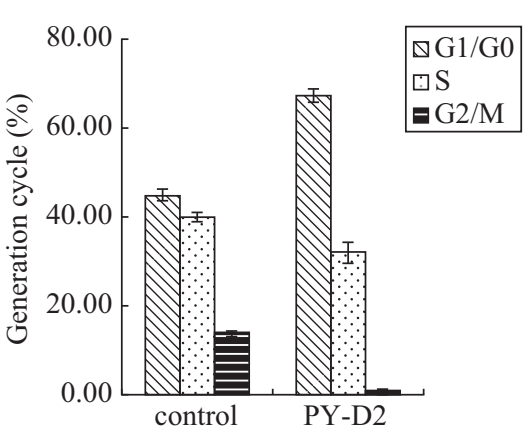

(a)

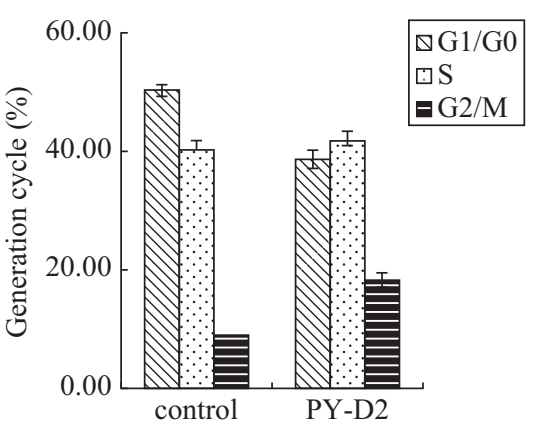

(c)

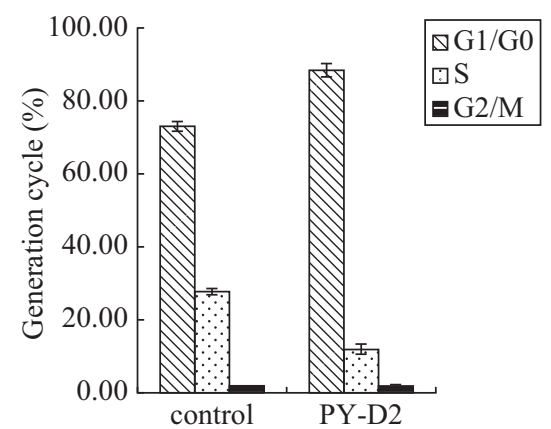

(b)

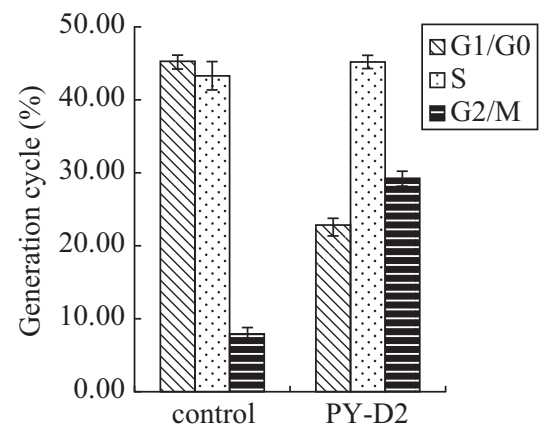

(d)

Fig. 4. (a) Effect of PY-D2 on the cell cycle of SMMC-7721 $(n=6, \bar{X} \pm S)$, (b) Effect of PY-D2 on the cell cycle of HO-8910 (n =6, $\bar{X} \pm S),(c)$ Effect of PY-D2 on the cell cycle of MCF-7 $(n=6, \bar{X} \pm S)$, (d) Effect of PY-D2 on the cell cycle of $K 562(n=6, \bar{X} \pm S)$. 


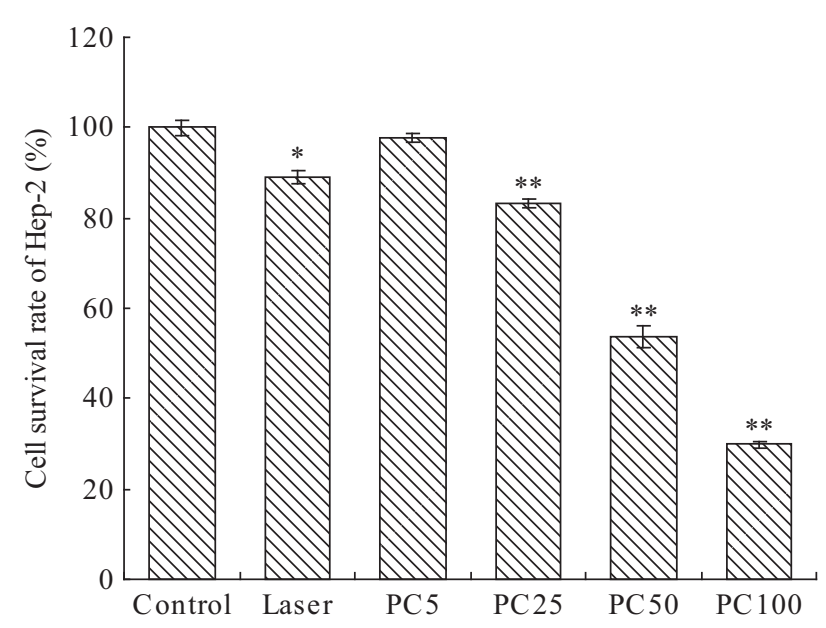

Fig. 5. Effect of phycocyanin (PC) from Porphyra yezoensis on Hep-2 $(\mathrm{n}=$ $6, \overline{\mathrm{X}} \pm \mathrm{S})\left({ }^{*} p<0.05,{ }^{* *} p<0.01\right)$.

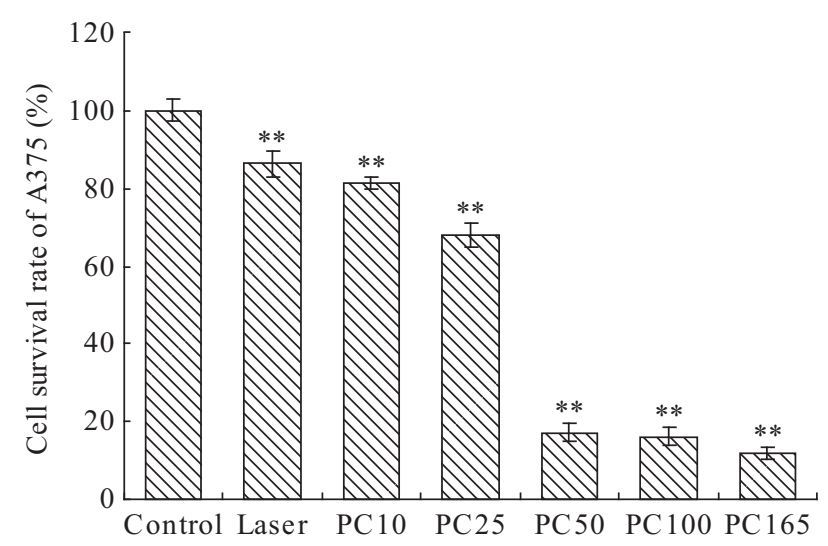

Fig. 6. Effect of phycocyanin (PC) from Porphyra yezoensis on A375 ( $\mathrm{n}=$ $6, \overline{\mathrm{X}} \pm S)(* * p<0.01)$

cytometry analyses showed that the polysaccharide from Porphyra yezoensis causes cancer cell cycle arrested at the $\mathrm{G} 0 / \mathrm{G} 1$ or the $\mathrm{G} 2 / \mathrm{M}$ check points.

Although our understanding on the mechanism underlying the anti-cancer effects of polysaccharide from Porphyra yezoensis is still far from complete, previous studies have shown that the algal polysaccharides may directly and/or indirectly inhibit the growth of tumor cells. The algal polysaccharides can prolong the cell cycle of the tumor cells or cause the tumor cells to undergo apoptosis by regulating signaling molecules such as NF- $\mathrm{KB}$, Smad3 [19]. The change of $\mathrm{Ca}^{2+}$ concentration [15] or the down-regulation of bcl-2 expression [32] induced by the algal polysaccharides can also lead the tumor cells to apoptosis. In addition, the algal polysaccharides can indirectly inhibit the growth of tumor cells by improving the immune functions or inhibiting DNA synthesis [39].

Besides, we have done some experiments about the effect of polysaccharide on other cells in our lab before. We have found the polysaccharide could advance the growth of mouse spleen lymphocytes, the result of flow cytometry indicated that polysaccharide from Porphyra yezoensis could promote mouse spleen lymphocytes to enter into $\mathrm{S}$ phase from G1 phase [37]. We also found that the polysaccharide from Porphyra yezoensis can obviously promote the growth of the rat sertoli cells [38]. So the inhibitory effect of polysaccharide from Porphyra yezoensis is not a general cytotoxicity of the chemicals on any cells, it is specific to the cancer cells.

Photodynamic therapies (PDT) for treating malignant tumors have been developed rapidly in recent years [1]. The photosensitizers can absorb luminous energy and convert oxygen to singlet oxygen $\left({ }^{1} \mathrm{O}_{2}\right)$, a powerful reactive oxygen species (ROS) that can kill tumor cells [14]. As a photosensitizer of potential important values in PDT, phycocyanin extracted from algae has attracted much attention [7]. Previous studies have reported that phycocyanin from Spirulina platensis inhibited the growth of human hepatocellular carcinoma cell line SMMC-7721 [4], human rectal cancer cell line HR8348 [12], and human leukemia HL-60, as well as K562 and U937 cell line [36]. Phycocyanin from Porphyra haitanensis was also reported to inhibit the growth of HL-60 cells [22]. Since phycocyanin from Porphyra yezoensis has not been investigated for such effects yet, our study presented the first report on the dose-dependent inhibitory effects of Porphyra yezoensis on the growth of various human tumor cells (Figs. 5 and 6). Our data also suggest phycocyanin from Porphyra yezoensis as a candidate for anti-cancer therapeutics in addition to the phycocyanins isolated form other algae.

The mechanism underlying the anti-tumor effects of phycocyanin may be related to the interference of DNA synthesis in tumor cells $[25,33]$ or the ability of phycocyanin to improve the immune functions [28, 29]. The most recent report showed that phycocyanin bound to the mitogen receptor on the tumor cell membrane and sitmulated the surface expression of CD59, thereby activating the cellular apoptotic signal transduction [17].

\section{ACKNOWLEDGMENTS}

We are grateful to professor Wei-hua Feng (Department of Molecular and Biochemical, Second Military Medical University) for helpful advice to our studies. This research was financially supported by State 863 Programs (No. 2006AA10 Z323 and No. 2007AA09Z406), Key Laboratory of Exploration and Utilization of Aquatic Genetic Resources, Shanghai Ocean University, Ministry of Education (No. KFT 2008-12), Program of Shanghai Subject Chief Scientist (08XD14037), Project of Shanghai Science and Technology Commission (08540702600), Shanghai Education Committee of China (Preponderant Subject Program\# S30701) and Shanghai Science Committee (Bio-Medicine Key Project \#054319936, Pujiang Plan \#05PJ14086).

\section{REFERENCES}

1. Cai, C. E., Wu, Q. L., and He, P. M., "Advance of phycoerythrin as a pho- 
tosensitizer," Letters in Biotechnology, Vol. 15, No. 6, pp. 629-632 (2004).

2. Cai, C. E., Wu, Q. L., and He, P. M., "Extraction and purification of R-phycoerythrin in Porphyra yezoensis," Letters in Biotechnology, Vol. 16, No. 5, pp. 518-521 (2005).

3. Cai, X. H., Zheng, S., and He, L. M., "The experimental study of application of phycocyanin in cancer laser therapy," Chinese Journal of Marine Drugs, Vol. 53, No. 1, p. 15 (1995).

4. Chen, X. M. and Wang, X. H., "The characteristics and anticancer activity of phycocyanin from S. platensis," Amino Acids \& Biotic Resources, Vol. 28 , No. 1, pp. 59-62 (2006)

5. Chen, Z. T., Wang, L. X., and Lin, W. Q., "Advances of studies on the phycocyanin in Spirulina," Strait Pharmaceutical Journal, Vol. 15, No. 6 pp. 1-5 (2003)

6. Dorey, K., Barila, D., and Cavin, A. C., "Regulation of human c-abltyrosine kinase activity in xenopus oocytes and acceleration of progesterone-induced G2/M transition by oncogenie forms," Biological Chemistry, Vol. 380, No. 2, pp. 223-230 (1999).

7. Glazer, A. N., "Phycobiliproteins - a family of valuable, widely used fluorophores," Journal of Applied Phycology, Vol. 6, pp. 105-110 (1994).

8. Gu, J. W., Zhang, L. X., and Xu, H. L., "Study on isolation, purification and antitumor activity of polysaccharides from Porphyra yezoensis," China Biotechnology, Vol. 27, No. 7, pp. 50-54 (2007).

9. Guo, T. T., Xu, H. L., and Zhang, L. X., "In vivo protective effect of Porphyra yezoensis polysaccharide against carbon tetrachloride induced hepatotoxicity in mice," Regulatory Toxicology and Pharmacology, Vol. 49, pp. 101-106 (2007).

10. Guo, T. T., Zhang, L. X., and Gu, J. W., "Study on effects of crude polysaccharide from Porphyra yezoensis on several different kinds of cells," Letters in Biotechnology, Vol. 17, pp. 359-361 (2005).

11. Hartwell, L. H. and Kastan, M. B., "Cell cycle control and cancer," Science, Vol. 266, pp. 1821-1828 (1994).

12. He, L. M., Cai, X. H., and Yu, L. L., "Photodynamic effect of phycocyanin with a pulsed copper vapour pumped dye laser irradiation on the human colorectal cancer cell line HR8348," Chinese Journal of Laser Medicine \& Surgery, Vol. 5, No. 2, pp. 90-92 (1996).

13. He, P. M. and Wu, W. N., "Establishment and cultivation of cell line HB with high temperature resistance and fast growth in Porphyra yezoensis," Acta Biologiae Experimentals Sinica, Vol. 36, pp. 191-196 (2003).

14. Huang, B., Wang, G. C., and Li, Z. G., "Antitumor studies of C-phycocyanin chromophore peptides mediated photodynamic therapy," Acta Laser Biology Sinica, Vol. 11, No. 3, pp. 194-198 (2002).

15. Ji, Y. B., Gao, S. Y., and Zhang, X. J., "Influence of sargassum fusiforme polysaccharide on apoptosis of tumor cells," China Journal of Chinese Materia Medica, Vol. 29, No. 3, pp. 245-247 (2004).

16. Koyanagi, S., Tanigawa, N., and Nakagawa, H., "Oversulfation of fucoidan enhances its anti-angiogenic and antitumor activities," Biochemical Pharmacology, Vol. 65, pp. 173-179 (2003).

17. Li, B., Zhang, X. C., and Gao, M. H., "Study of regulatory effect of phycocyanin on CD59 gene expression of Hela cells," High Technology Letters, Vol. 16, No. 2, pp. 196-200 (2006).

18. Li, W. X., Zhu, Z. J., and Liu, F. X., Phycology Generality, Shanghai Sci. \& Technol. Press, Shanghai (1982).

19. Lin, Y. L., Liang, Y. C., and Lee, S. S., "Polysaccharide purified from Ganoderma lucidum induced activation and maturation of human monocyte-derived dendritic cells by the NF- NF- $\mathrm{kB}$ and $\mathrm{p} 38$ mitogen-activated protein kinase pathways," Journal of Leukocyte Biology, Vol. 78, pp. 533 543 (2005)

20. Liu, F., Liao, Z. K., and He, P. M., "Effects of several factors to primary extraction of polysaccharides from Porphyra," Journal of Shanghai Fisheries University, Vol. 14, No. 1, pp. 26-29 (2005).

21. Liu, F., Liu, J., Gu, J. W., Zhang, L. X., Shen, W. R., and Guo, T. T., "Ex vivo antioxidation activity of polysaccharides from the red alga Porphyra yezoensis," Ciencias Marinas, Vol. 43, No. 2, pp. 1-9 (2008).

22. Liu, Y. F., Xu, L. Z., and Chen, N., "Inhibitory effect of phycocyanin from Spirulina platensis on the growth of human leukemia K562 cells," Journal of Applied Phycology, Vol. 12, No. 2, p. 125 (2000).

23. Liu, Y. F., Xu, L. Z., and Zhang, C. W., "The inhibition of phycocyanin from Porphyra haitanensis on the on the growth of human leukemia HL-60 cells," Chinese Journal of Marine Drugs, Vol. 19, No. 1, p. 20 (2000).

24. Mishima, T., Murata, J., and Toyoshima, M., "Inhibition of tumor invasion and metastasis by calcium spirulan (Ca-SP), a novel sulfated polysaccharide derived from a blue-green alga, Spirulina platensis," Clinical \& Experimental Metastasis, Vol. 16, No. 6, p. 541 (1998).

25. Morcos, N. C., "Phycocyanin laser activation cytotoxic effect and uptske in human atherosclerotic plaque," Lasers in Surgery and Medicine, Vol. 8, No. 1, pp. 7-10 (1988).

26. Nasmyth, K., "Viewpoint: putting the cell cycle in order," Science, Vol. 274, pp. 1643-1645 (1996).

27. Pardhasaradhi, B. V. V., Ali, M., and Kumari, A. L., "Phycocyanin-mediated apoptosis in AK-5 tumor cells involves down-regulation of Bcl-2 and generation of ROS," Molecular Cancer Therapeutics, Vol. 2, p. 1165 (2003).

28. Romay, C., Gonzalez, R., and Ledon, N., "C-phycocyanin: a biliprotein with antioxidant, anti-inflammatory and neuroprotective effects," Current Protein \& Peptide Science, Vol. 4, No. 3, pp. 207-216 (2003).

29. Romay, C., Ledon, N., and Gonzalez, R., "Effects of phycocyanin extract on prostaglandin E2 levels in mouse ear inflammation tests," Arzneimittel Forschung, Vol. 50, No. 12, pp. 1106-1109 (2000).

30. Schwartz, J. L. and Sklar, G., "Growth inhibition and destruction of oral cancer cells by extracts of Spirulina," Proceeding of American Academy of Oral Pathology, Vol. 40, pp. 23-27 (1986).

31. Suetsuna, K., "Purification and identification of angiotensin I-converting enzyme inhibitors from the red alga Porphyra yezoensis," Journal of Marine Biotechnology, Vol. 6, pp. 163-167 (1998).

32. Sun, D. Y., Lin, H., and Shi, Y. X., "Effect of laminaria polysaccharidesulfate on proliferation and apoptosis in HeLa cell," The Journal of Practical Medicine, Vol. 21, No. 12, pp. 1241-1243 (2005).

33. Wang, Y., Qian, F., and Qian, K. X., "Anticancer activity of phycocyanin," Journal of Zhejiang University (Engineering Science), Vol. 35, No. 6, pp. 672-675 (2001).

34. Yoshizawa, Y., Ametani, A., and Tsunehiro, J., "Macrophage stimulation activity of the polysaccharide fraction from a marine alga (Porphyra yezoensis): structure-function relaionships and improved solubility," Bioscience Biotechnology and Biochemistry, Vol. 59, No. 10, p. 1933 (1995).

35. Zeng, X. Y., Oncology, People's Medical Publishing House, Beijing (1999).

36. Zhang, C. W., Liu, Y. F., and Shen, H. Y., "The effect of phycocyanin from Spirulina platensis on the growth of human leukaemia cell," Marine Sciences, Vol. 24, No. 1, pp. 45-48 (2000).

37. Zhang, L. X., Xu, H. L., and Gu, J. W., "Effect of Porphyra yezoensis polysaccharide PY-D2 on mouse spleen lymphocytes," Chinese Journal of Immunology, Vol. 23, No. 12, pp. 1093-1096 (2007)

38. Zhang, W. Y., Zhou, J. F., and Chen, H., "Effects of a polysaccharide from Porphyra yezoensis on murine immunocytes and human leukemia K562 Cells," Life Science Research, Vol. 6, pp. 168-170 (2002).

39. Zhou, G., Sheng, W., and Yao, W., "Effect of low molecular lambda-carrageenan from Chondrus ocellatus on antitumor H-22 activity of 5-Fu," Pharmacological Research, Vol. 53, No. 2, pp. 129-134 (2006).

40. Zhu, L. P. and Chen, X. Q., Experimental Techniques of Immunology, People's Military Medical Press, Beijing (2000). 